Finisterra, XXXVII, 74, 2002, pp. 199-201

\title{
CONFERENNCIA ANUAL DA REAL SOCIEDADE DE GEOGRAFIA E DO INSTITUTO DOS GEÓGRAFOS BRITÂNICOS - 2002
}

\author{
Alina Esteves ${ }^{1}$
}

A Conferência de 2002 da Real Sociedade de Geografia e do Instituto dos Geógrafos Britânicos (Royal Geographical Society - Institute of British Geographers) decorreu entre os dias 2 e 5 de Janeiro na cidade britânica de Belfast, localizada na Irlanda do Norte. Ao fim de várias décadas de terrorismo, a cidade apresenta finalmente condições políticas favoráveis à realização de eventos internacionais de grande magnitude.

A Escola de Geografia da Queen's University de Belfast foi a entidade organizadora desta Conferência, cujos quatro temas principais reflectem a realidade da República da Irlanda e da província britânica da Irlanda do Norte: as Migrações; a Complexidade e o Caos; a Paisagem e Cidades Divididas; Comunidades Divididas.

O Departamento de Geografia desta Universidade apresenta uma especialização em temas ligados à Geomorfologia, pois durante a década de setenta formou, conjuntamente com os Departamentos de Arqueologia, Paleontologia e Geologia, a Escola das Geociências. Só muito recentemente, já no ano 2000, voltou a ser um Departamento autónomo.

Durante a Conferência, foram apresentadas 419 comunicações repartidas pelas várias sessões promovidas por 23 Grupos de Investigação. Este ano predominaram as sessões conjuntas revelando que geógrafos de áreas distintas podem trabalhar em conjunto para melhor compreenderem a complexidade do planeta.

O Grupo de Investigação das Área Montanhosas realizou sessões com o Grupo da Geomorfologia e com o Grupo da Geografia do Lazer e do Turismo, apresentando os resultados da investigação realizada sobre a erosão do solo nas terras altas do Iémen, e a utilização dos SIG para quantificar o transporte de sedimentos nas regiões subárticas, procurando elaborar cenários para o futuro. O comportamento dos visitantes e a degradação ambiental das sensíveis paisagens do sudoeste de Inglaterra, os impactes ambientais do turismo na área de paisagem protegida do Anapurna no Nepal, ou a sustentabilidade e gestão ambiental no Paquistão foram outros dos temas abordados.

O Grupo de Investigação do Planeamento e Ambiente promoveu as suas sessões em torno da Agenda 21, focando a implementação do Protocolo de

\footnotetext{
1 Assistente do Departamento de Geografia da FLUL e investigadora do Centro de Estudos Geográficos. E-mail: alinaesteves@eurodivisal.com
} 
Quioto nos países da União Europeia e o papel desempenhado pelas cidades na alterações do clima, pois constituem locais onde se geram elevados volumes de poluentes e é notório o efeito de estufa.

O Grupo de Investigação da Geografia da População realizou uma interessante sessão sobre migrações internacionais abordando as políticas de imigração e de acolhimento de refugiados no Reino Unido e na República da Irlanda, e na sua sessão conjunta com o Grupo de Investigação da Geografia da Saúde, foram abordados os impactes da chegada de cidadãos estrangeiros na alteração dos padrões de mortalidade e de doenças várias no Reino Unido.

O uso da internet nas aulas de Geografia para alunos dos países em vias de desenvolvimento e a importância das viagens de estudo dos geógrafos recém-licenciados ao continente africano, onde contactam com realidades muito distintas dos seus países de origem, foram os principais temas da sessão que reuniu os estudiosos dos Grupos de Investigação do Ensino Superior e das Áreas em Desenvolvimento.

Foi organizada uma sessão subordinada ao tema: as Tecnologias de Informação e os Geógrafos, onde os investigadores de diversas áreas mostraram a utilidade dos SIG no estudo dos padrões de incidência do cancro do pulmão, bem como a utilização da teledetecção hiper e multi-espectral no estudo da degradação das áreas húmidas na região de La Mancha, Espanha.

O Grupo de Investigação da Geografia Económica dedicou a sua sessão à regulação das comunidades, das redes económicas e das políticas, focando os temas da europeização das políticas de imigração e asilo, as redes alternativas de distribuição de produtos alimentares na Comunidade Europeia e a participação dos cidadãos na governação local na África do Sul.

As sessões conjuntas do Grupo de Investigação da Geografia Rural com os Grupos da Paisagem e da Geografia Histórica debruçaram-se sobre a paisagem e as práticas tradicionais de gestão agrícola nas Montanhas Pindos na região noroeste da Grécia, bem como sobre as alterações ambientais e económicas na região dos Cárpatos na Roménia após a deposição do presidente Ceausescu. A mobilidade da mão-de-obra agrícola desde o século XVIII no Reino Unido e as restrições impostas à migração para espaços rurais no sul da Suécia no século XIX foram outros dos temas apresentados.

O Renascimento Urbano e as cidades divididas foram os temas chave das sessões dos Grupos de Investigação da Geografia Urbana e da Geografia Política. As apresentações focaram os processos de nobilitação, renovação e revitalização urbana defendidos no Reino Unido, as tensas relações entre israelitas e palestinianos em Jerusalém e o período pós-apartheid nas cidades sul-africanas.

Os Grupos de Investigação de Geomorfologia e dos Métodos Quantitativos organizaram um sessão sobre o caos, fractais e a organização dos sistemas hidrodinâmicos e das superfícies desérticas. Foram divulgados resultados de estudos realizados sobre a previsibilidade do comportamento dos meandros dos rios, origem e influência das coberturas rochosas na escorrência das águas no deserto da Jordânia e importância dos fractais nos estudos de microrelevo. 
Seguindo a orientação geral da Conferência, o Grupo de Investigação das Geografias Pós-Socialistas dedicou a sua sessão às comunidades divididas, tendo os participantes apresentado resultados sobre a identidade, nacionalismo e política na Bosnia-Herzegovina após a assinatura do Acordo de Dayton em 1995, mas também sobre os problemas resultantes do reforço da defesa armada da fronteira entre duas antigas repúblicas soviéticas, o Usbequistão e o Quirguistão, ou ainda sobre as dificuldades sentidas pela população rural da ex-Alemanha Democrática em encontrar o seu lugar na Alemanha unificada.

As experiências de naturalização e de exercício de cidadania das mulheres vietnamitas no Japão e na Austrália, e a inserção dos trabalhadores indianos do sector das Tecnologias de Informação imigrados na Alemanha ao abrigo das novas disposições de recrutamento de trabalhadores qualificados, foram alguns dos assuntos abordados na sessão do Grupo de Investigação da Geografia Social e Cultural.

Para além das sessões promovidas pelos diversos Grupos de Investigação, a organização conseguiu reunir um conjunto de palestrantes extremamente interessante e variado. As conferências à hora do almoço abordaram temas como as viagens de Humboldt e a importância dos conceitos de paisagem, ecologia, evolução e ecúmena (Prof. ${ }^{a}$ Anne Buttimer), a necessidade de formar alunos aptos a utilizarem novos e sofisticados instrumentos como os SIG e a teledetecção nas suas investigações de Geografia Física e Biogeografia (Prof. Glen MacDonald), e a profissionalização do Ensino Superior, nomeadamente no que diz respeito à formação dos professores (Prof. ${ }^{a}$ Sally Brown).

Os participantes da Conferência podiam ainda optar por cinco excursões. Uma viagem de estudo ao monte Mourne, onde se observaram as estratégias adoptadas para atrair e acolher visitantes minimizando os impactes ambientais. A segunda excursão consistia numa visita aos elementos marcantes da paisagem cultural do nordeste do Ulster, como a Calçada dos Gigantes com a suas inúmeras colunas de basalto e a região de Bushmills, muito conhecida pelas destilarias de whisky e moinhos movidos a água.

A terceira visita de estudo constava de um passeio pela cidade de Londonderry, segundo maior aglomerado populacional da Irlanda do Norte, incluindo apresentações feitas por grupos de residentes dos bairros católicos e protestantes sobre a sua vivência de uma cidade que, até há muito pouco tempo, convivia diariamente com a violência. Foi igualmente possível realizar uma visita por Belfast conhecendo o seu crescimento ao longo da história ou assistir a uma apresentação do projecto «Espaços do Medo» sobre a dividida cidade de Belfast onde diariamente católicos e protestantes têm de negociar a partilha do espaço.

Procurando responder às solicitações dos membros, as próximas conferências decorrerão sempre em Setembro, antes do ano lectivo ser iniciado, e a organização ficará entregue à Real Sociedade de Geografia, que disponibilizará as suas magníficas e renovadas instalações em Londres para tais eventos. A Conferência de 2003 será subordinada ao tema A Geografia ao Serviço da Sociedade e do Ambiente. 